\title{
PENGARUH PENDAPATAN ASLI DAERAH DAN DANA ALOKASI UMUM TERHADAP PENGALOKASIAN ANGGARAN BELANJA MODAL
}

(STUDI EMPIRIS PADA PEMERINTAH PROVINSI SE-PROVINSI JAMBI 2009-2017)

\section{THE INFLUENCE OF OWN SOURCE REVENUE (PAD) AND GENERAL ALLOCATION GRANT (DAU) ON CAPITAL EXPENDITURE}

(EMPIRICAL STUDY ON JAMBI PROVINCE GOVERNMENT 2009-2017)

\author{
Parassela Pangestu P ${ }^{1)}$, Meutia Riany ${ }^{2)}$, Elisabeth Paramita J.S ${ }^{3)}$, Endah Sundaning K ${ }^{4)}$ \\ 1,2,3,4) Mahasiswa Magister Akuntansi Fakultas Ekonomi dan Bisnis \\ Universitas Padjajaran
}

pprimadiva@gmail.com ${ }^{1)}$, meutiariyu25@gmail.com ${ }^{2)}$, sihotang.elizabeth09@ gmail.com ${ }^{3)}$, endasuminar@gmail.com ${ }^{4}$

1,2,3,4) Email Author

\begin{abstract}
This research is aimed to know the influence of Own Source Revenue (PAD) and General Allocation Grant (DAU) towards capital expenditure. Samples used in this research are 9 regencies, 2 cities, and 1 Province from 2009 to 2017. They are Batanghari, Bungo, Kerinci, Merangin, Muaro Jambi, Sarolangun, Tanjung Jabung Timur, Tanjung Jabung Barat, Tebo regency, Jambi and Sungai Penuh city, also Jambi Province. Data analysis used in this research is multiple linear regression analysis using software SPSS ver.22 for windows. The results of this research showed as followed. First hypothesis, Own Source Revenue (PAD) and General Allocation Grant (DAU) have influence towards capital expenditure. Second hypothesis, Own Source Revenue (PAD) has significant influence towards capital expenditure. Third hypothesis General Allocation Grant (DAU) has no significant influence towards capital expenditure
\end{abstract}

Keywords : Own Source Revenue (PAD, General Allocation Grant (DAU), capital expenditure, Jambi Province, multiple linear regression analysis, SPSS 22

\begin{abstract}
ABSTRAK
Penelitian ini bertujuan untuk menguji pengaruh Pendapatan Asli Daerah (PAD) dan Dana Alokasi Umum (DAU) terhadap belanja modal. Penelitian ini menggunakan sampel Kabupaten dan Kota di Provinsi Jambi periode 2009 - 2017. Ada 9 Kabupaten, 2 Kota, dan 1 Provinsi yang menjadi subjek penelitian ini, yaitu Kabupaten Batanghari, Kabupaten Bungo, Kabupaten Kerinci, Kabupaten Merangin, Kabupaten Muaro Jambi, Kabupaten Sarolangun, Kabupaten Tanjung Jabung Timur, Kabupaten Tanjung Jabung Barat, Kabupaten Tebo, Kota Jambi dan Kota Sungai Penuh, serta Provinsi Jambi. Penelitian ini menggunakan data sekunder yang diperoleh dari Laporan Keuangan masing-masing pemerintah daerah. Data penelitian berjumlah 60 data. Teknik analisis data dalam penelitian ini analisis regresi linear berganda dengan menggunakan software SPSS versi 22 for windows. Hasil penelitian adalah sebagai berikut. Hipotesis pertama, hasil menunjukkan bahwa PAD dan DAU berpengaruh terhadap belanja modal. Hipotesis kedua, PAD berpengaruh terhadap belanja modal. Hipotesis ketiga DAU tidak berpengaruh terhadap belanja modal.
\end{abstract}

Kata Kunci : Pendapatan Asli Daerah (PAD), Dana Alokasi Umum (DAU), belanja modal, Provinsi Jambi, analisis regresi linear berganda, SPSS 22 


\section{PENDAHULUAN}

\subsection{Latar Belakang}

Adanya implementasi otonomi daerah dan desentralisasi fiskal di Indonesia yang ditandai dengan Undang-undang Nomor 32 Tahun 2004 dan Undangundang Nomor 33 Tahun 2004, membawa implikasi tersendiri dalam proses pembangunan di daerah, yaitu dengan adanya perubahan pola penerimaan dan pengeluaran daerah dalam Anggaran Pendapatan dan Belanja Daerah (APBD). Dana Perimbangan Pemerintah Pusat-Daerah yang diberikan dalam UU No 33 Tahun 2004 meliputi Dana Bagi Hasil, Dana Alokasi Umum (DAU) dan Dana Alokasi Khusus (DAK). Perimbangan keuangan seyogyanya adalah untuk mewujudkan pemerintahan yang bersifat desentralisasi. DAU, DAK, Dana Bagi Hasil bersama dengan Pendapatan Asli Daerah (PAD) merupakan sumber dana daerah yang digunakan untuk menyelenggarakan pemerintahan di tingkat daerah dengan kewenangan menentukan alokasi sumber daya ke dalam belanja modal dengan menganut asas kepatutan, kebutuhan dan kemampuan daerah

Anggaran sektor publik pemerintah daerah dalam APBD sebenarnya merupakan pengalokasian sumberdaya. Adapun pengalokasian sumberdaya merupakan permasalahan dasar dalam penganggaran sektor publik. Keterbatasan sumberdaya sebagai pangkal masalah utama dalam pengalokasian anggaran sektor publik dapat diatasi dengan pendekatan ilmu ekonomi melalui berbagai teori tentang teknik dan prinsip seperti yang dikenal dalam public expenditure management.

Pemerintah daerah mengalokasikan dana dalam bentuk anggaran belanja modal dalam APBD untuk menambah aset tetap. Alokasi belanja modal ini didasarkan pada kebutuhan daerah akan sarana dan prasarana, baik untuk kelancaran pelaksanaan tugas pemerintahan maupun untuk fasilitas publik. Oleh karena itu, dalam upaya meningkatkan kualitas pelayanan publik, pemerintah daerah seharusnya mengubah komposisi belanjanya. Pemanfaatan belanja hendaknya dialokasikan untuk hal-hal produktif dan lebih banyak untuk program-program layanan publik (Darwanto \& Yustikasari, 2007).

Desentralisasi fiskal memberikan kewenangan yang besar kepada daerah untuk menggali potensi yang dimiliki sebagai sumber pendapatan daerah untuk membiayai pengeluaran daerah dalam rangka pelayanan publik. Infrastuktur dan sarana prasarana yang ada di daerah akan berdampak pada pertumbuhan ekonomi daerah. Jika sarana dan prasarana memadai maka masyarakat dapat melakukan aktivitas sehariharinya secara aman dan nyaman yang akan berpengaruh pada tingkat produktivitasnya yang semakin meningkat, dan dengan adanya infrastruktur yang memadai akan menarik investor untuk membuka usaha di daerah tersebut. Dengan bertambahnya belanja modal maka akan berdampak pada periode yang akan datang yaitu produktivitas masyarakat meningkat dan bertambahnya investor akan meningkatkan PAD.

Setiap daerah mempunyai kemampuan keuangan yang tidak sama dalam mendanai kegiatan-kegiatannya, hal ini menimbulkan ketimpangan fiskal antara satu daerah dengan daerah lainnya. Oleh karena itu, untuk mengatasi ketimpangan fiskal ini Pemerintah mengalokasikan dana yang bersumber dari APBN untuk mendanai kebutuhan daerah dalam pelaksanaan desentralisasi. Salah satu dana perimbangan dari pemerintah ini adalah DAU yang pengalokasiannya menekankan aspek pemerataan dan keadilan yang selaras dengan penyelenggaraan urusan pemerintahan (UU No.33 Tahun 2004). Dengan adanya transfer dana dari pusat ini diharapkan pemerintah daerah bisa lebih mengalokasikan PAD yang didapatnya untuk membiayai belanja modal daerahnya.

Jika Dana Alokasi Umum (DAU) dan Pendapatan Asli Daerah (PAD) yang didapatkan pemerintah semakin meningkat maka belanja modal oleh pemerintah daerah juga akan meningkat dan akan memberikan hasil pemenuhan kebutuhan infrastruktur serta sarana prasarana bagi Provinsi Jambi (Darwanto \& Yustikasari, 2007; Hariyanto dan Adi, 2003; Putro \& Pamudji, 2007; Frelistiyani, 2010; Wertianti \& Dwirandra, 2013; Swastika, 2013)

\subsection{Rumusan Masalah}

1. Apakah PAD berpengaruh positif terhadap pengalokasian anggaran belanja modal pada Pemerintahan se-Provinsi Jambi?

2. Apakah DAU berpengaruh positif terhadap pengalokasian anggaran belanja modal pada Pemerintahan se-Provinsi Jambi?

3. Apakah PAD dan DAU berpengaruh terhadap pengalokasian anggaran belanja modal pada Pemerintahan se-Provinsi Jambi?

\section{TINJAUAN PUSTAKA, KERANGKA PEMIKIRAN DAN HIPOTESIS}

\subsection{Tinjauan Pustaka}

\subsection{Otonomi Daerah}

Otonomi daerah dewasa ini telah menjadi semacam new product dari sebuah "industri" bernama pemerintah yang begitu masuk di pasar langsung memperoleh tanggapan sangat tinggi. Otonomi daerah menjadi sesuatu yang marketable dari berbagai sisi dan bidang kajian. Di satu pihak, otonomi daerah memberikan harapan baru terhadap tumbuhnya kesadaran untuk membangun daerah secara lebih optimal, tidak lagi terkonsentrasi di Pusat. Namun di pihak lain otonomi daerah menghadirkan kekhawatiran munculnya "desentralisasi masalah" dan "desentralisasi kemiskinan". Artinya pelimpahan dari beberapa wewenang dari Pusat di daerah juga disertai dengan pelimpahan masalah dan kemiskinan yang selama ini 
tidak dapat ditangani dan diselesaikan oleh pemerintah pusat. (Ulum, 2008).

Pada reformasi sektor publik yang disertai adanya tuntutan demokratisasi menjadi suatu fenomena global. Tuntutan demokratisasi ini menyebabkan sistem pengelolaan keuangan daerah mampu memberikan nuansa manajemen keuangan yang lebih adil, rasional, transparan, partisipatif, akuntabilitas dan bertanggung jawab. Aspek yang paling penting yaitu akuntabilitas dan transparansi dalam pengelolaan pemerintah termasuk di bidang pengelolaan keuangan negara maupun daerah.

Mardiasmo (2002) mengungkapkan pemberian informasi dan pengungkapan seluruh aktivitas dan kerja finansial Pemerintah Daerah kepada pihak-pihak yang berkepentingan. Untuk mewujudkan transparansi telah dikeluarkan Peraturan Pemerintah Nomor 56 Tahun 2006 tentang Sistem informasi Keuangan Daerah yang pada intinya pemerintah daerah wajib menyajikan informasi keuangan daerah secara terbuka kepada masyarakat, konsekuensinya setiap pemerintah daerah harus membangun sistem informasi keuangan daerah. Tuntutan transparansi dan akuntabilitas publik begitu sering ditujukan kepada para manajer pemerintah di daerah. Seiring dengan itu semua Peraturan Pemerintah No. 105 Tahun 2000 juga mensyaratkan pertanggungjawaban keuangan dalam bentuk laporan keuangan yaitu berupa Neraca Daerah, Arus Kas, dan Realisasi Anggaran, bagi kepala daerah. Hal itu semua pada akhirnya menuntut kemampuan manajemen daerah untuk mengalokasikan sumber daya secara efisien dan efektif.

\subsubsection{Pendapatan Asli Daerah (PAD)}

Sesuai dengan Undang-Undang No.33 Tahun 2004 tentang Perimbangan Keuangan antara Pemerintah Pusat dan daerah pasal 6 bahwa Sumber Pendapatan Asli Daerah adalah dari hasil daerah itu sendiri dan sumbangan pemerintah, yaitu sebagai berikut:

1) Hasil Pajak Daerah

2) Hasil Retribusi Daerah

3) Hasil Perusahaan Milik Daerah dan hasil pengelolaan kekayaan daerah lainnya yang dipisahkan

4) Sumbangan dari pemerintah

5) Sumbangan lain yang diatur dengan peraturan perundangan

6) Pendapatan lain-lain yang sah

Peningkatan pendapatan daerah dapat dilaksanakan melalui beberapa langkah, diantaranya adalah intensifikasi dari pajak dan retribusi daerah, eksentifikasi dari penggalian sumber-sumber penerimaan baru, dan peningkatan pelayanan kepada masyarakat.

\subsubsection{Dana Alokasi Umum (DAU)}

Dana Alokasi Umum merupakan salah satu transfer dana Pemerintah kepada pemerintah daerah yang bersumber dari pendapatan APBN, yang dialokasikan dengan tujuan pemerataan kemampuan keuangan antar daerah untuk mendanai kebutuhan daerah dalam rangka pelaksanaan desentralisasi.

DAU bersifat "Block Grant" yang berarti penggunaannya diserahkan kepada daerah sesuai dengan prioritas dan kebutuhan daerah untuk peningkatan pelayanan kepada masyarakat dalam rangka pelaksanaan otonomi daerah. Besaran DAU ditetapkan sekurang-kurangnya 26\% dari Pendapatan Dalam Negeri (PDN) Netto yang ditetapkan dalam APBN. Proporsi DAU untuk daerah provinsi dan untuk daerah kabupaten/kota ditetapkan sesuai dengan imbangan kewenangan antara propinsi dan kabupaten/kota.

\subsubsection{Belanja Modal}

Menurut Kementrian Keuangan Republik Indonesia Direktorat Jendral Anggaran, Belanja modal merupakan pengeluaran anggaran yang digunakan dalam rangka memperoleh atau menambah aset tetap dam aset lainnya yang memberi manfaat lebih dari satu periode akuntansi serta melebihi batasan minimal kapitalisasi aset tetap atau aset lainnya yang ditetapkan pemerintah.

Belanja Modal dapat diaktegorikan dalam 5 (lima) kategori utama (Syaiful, 2006):

\section{Belanja Modal Tanah}

Pengeluaran biaya yang digunakan untuk pengadaan, pembeliaan, pembebasan penyelesaian, balik nama dan sewa tanah, pengosongan, pengurugan, perataan, pematangan tanah, pembuatan sertifikat, dan pengeluaran lainnya sehubungan dengan perolehan hak atas tanah dan sampai tanah dimaksud dalam kondisi siap pakai.

\section{Belanja Modal Peralatan dan Mesin}

Pengeluaran/biaya yang digunakan untuk pengadaan, penambahan, penggantian, dan peningkatan kapasitas peralatan dan mesin serta inventaris kantor yang memberikan manfaat lebih dari 12 (dua belas) bulan dan sampai peralatan dan mesin dimaksud dalam kondisi siap pakai.

\section{Belanja Modal Gedung dan Bangunan}

Pengeluaran biaya yang digunakan untuk pengadaan, penambahan, penggantian, dan termasuk pengeluaran untuk perencanaan, pengawasan dan pengelolaan pembangunan gedung dan bangunan yang menambah kapasitas sampai gedung dan bangunan dimaksud dalam kondisi siap pakai.

\section{Belanja Modal Jalan, Irigasi dan Jaringan}

Pengeluaran/biaya yang digunakan untuk pengadaan, penambahan, penggantian, peningkatan pembangunan/ pembuatan serta perawatan, dan termasuk pengeluaran untuk perencanaan, pengawasan dan pengelolaan jalan irigasi dan jaringan yang menambah kapasitas sampai 
jalan irigasi dan jaringan dimaksud dalam kondisi siap pakai.

\section{Belanja Modal Fisik Lainnya}

Pengeluaran atau biaya yang digunakan untuk pengadaan, penambahan, penggantian pembangunan atau pembuatan serta perawatan fisik lainnya yang tidak dikategorikan kedalam kriteria belanja modal tanah, peralatan dan mesin, gedung dan bangunan, dan jalan irigasi dan jaringan, termasuk dalam belanja ini adalah belanja modal kontrak sewa beli, pembelian barang-barang kesenian, barang purbakala dan barang untuk museum, hewan ternak dan tanaman, buku-buku, dan jurnal ilmiah

\subsection{Kerangka Pemikiran}

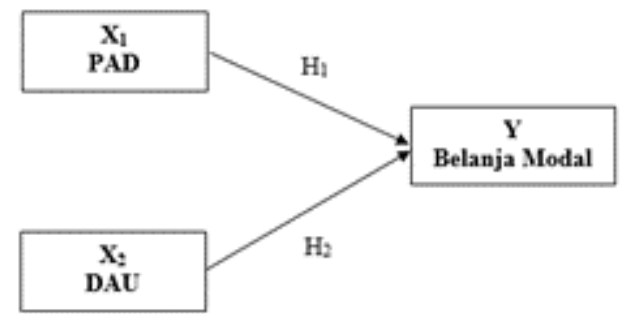

Penelitian ini menggunakan dua variabel independent yaitu Pendapatan Asli Daerah dan Dana Alokasi Umum serta variabel dependen berupa Belanja Modal.

Penyerahan wewenang pemerintahan oleh pemerintah pusat kepada pemerintah daerah untuk mengatur dan mengurus urusan pemerintahan dalam Sistem Negara Kesatuan Republik Indonesia diikuti dengan pemberian dana perimbangan (DAU). Hal ini disebabkan karena tidak semua daerah menghasilkan kekayaan alam.

Berdasarkan penelitian Holtz-Eakin et.al (1994) yang menyatakan keterkaitan sangat era antara transfer dari pemerintah pusat dengan belanja modal, maka peneliti ingin meneliti pengaruh PAD dan DAU terhadap Belanja Modal.

\subsection{Hipotesis}

Berdasarkan kerangka penelitian yang telah dipaparkan, maka peneliti merumuskan hipotesis sebagai berikut:

H1: Pendapatan Asli Daerah berpengaruh positif terhadap pengalokasian anggaran Belanja Modal

PAD merupakan andalan utama daerah untuk mendukung penyelenggaraan pemerintahan dan pembiayaan pembangunan, tetapi penerimaan daerah dari unsur PAD saja belum mampu memenuhi kebutuhan daerah apalagi dengan penambahan wewenang daerah jelas akan membutuhkan dana tambahan bagi daerah sehingga daerah masih tetap membutuhkan bantuan atau dana yang berasal (Darwanto \& Yustikasari, 2007).
Jika Pemda akan mengalokasikan belanja modal maka harus benar-benar disesuaikan dengan kebutuhan daerah dengan mempertimbangkan PAD yang diterima. Besar kecilnya belanja modal akan ditentukan dari besar kecilnya PAD, tujuan ini untuk meningkatkan pelayanan publik dan kesejahteraan masyarakat dengan jalan meningkatkan belanja modal, maka Pemda harus berusaha keras untuk menggali PAD yang sebesarbesarnya.

H2: Dana Alokasi Umum berpengaruh positif terhadap pengalokasian anggaran Belanja Modal

DAU merupakan salah satu sumber pembiayaan untuk belanja modal guna pengadaan sarana dan prasarana dalam rangka pemberian pelayanan publik yang baik dari pemerintah daerah kepada masyarakat. Bedanya, kalau PAD berasal dari uang masyarakat sedangkan DAU berasal dari transfer APBN yang dialokasikan dengan tujuan pemerataan keuangan antar daerah untuk membiayai kebutuhan pengeluarannya dalam rangka pelaksanaan desentralisasi.

Penelitian yang dilakukan oleh Darwanto \& Yustikasari (2007) dan Putro \& Pamudji (2007) menjukkan hasil bahwa DAU berpengaruh secara terhadap belanja modal. Hal ini disebabkan karena dengan adanya transfer DAU dari pemerintah pusat maka pemerintah daerah bisa mengalokasikan pendapatannya untuk membiayai belanja modal.

\section{METODOLOGI PENELITIAN}

\subsection{Populasi dan Sampel}

Populasi penelitian adalah pemerintah daerah Provinsi Jambi. Sampel penelitian adalah kabupaten dan kota di Sumatera yang memiliki pendapatan daerah aktif, dapat membiayai daerahnya sendiri dimana Kabupaten dan Kota tersebut menerbitkan Laporan Realisasi APBD tahun 2009-2017. Menggunakan teknik sampling Saturation sampling (sampling jenuh).

Data sekunder diambil dari Laporan Realisasi APBD tahun 2009-2017, yang diperoleh dari situs Dirjen Perimbangan Keuangan Pemerintah Daerah. Data Produk Domestik Regional Bruto (PDRB) per Kapita diperoleh dari Badan Pusat Statistik (BPS).

\subsection{Variabel Penelitian}

\subsubsection{Variabel Independen}

\subsubsection{Pendapatan Asli Daerah (PAD)}

Pendapatan Asli Daerah, selanjutnya disebut PAD adalah pendapatan yang diperoleh daerah yang dipungut berdasarkan peraturan daerah sesuai dengan peraturan perundang-undangan yang dirumuskan (Putro \& Pamudji, 2007): 


\section{$P A D=H P D+R D+P L P D+L P S$}

\section{Keterangan:}

HPD : Hasil Pajak Daerah

RD : Retribusi Daerah

PLPD : Pendapatan dari Laba Perusahaan Daerah

LPS : Lain-lain Pendapatan yang Sah

\subsubsection{Dana Alokasi Umum (DAU)}

DAU untuk suatu daerah dialokasikan atas dasar celah fiskal dan alokasi dasar. Celah fiskal adalah kebutuhan fiskal dikurangi dengan kapasitas fiskal daerah sedangkan alokasi dasar dihitung bedasarkan jumlah gaji Pegawai Negeri Sipil Daerah. Kebutuhan fiskal daerah merupakan kebutuhan pendanaan daerah untuk melaksanakan fungsi layanan dasar umum dimana kebutuhan pendanaan tersebut diukur secara berturut-turut dengan jumlah penduduk, luas wilayah, Indeks, kemahalan konstruksi, Produk Domestik Regional Bruto per Kapita dan Indeks Pembangunan Manusia. Kapasitas fiskal daerah merupakan sumber pendanaan daerah yang berasal dari PAD dan Dana Bagi Hasil. Sehingga DAU untuk daerah provinsi maupun daerah kabupaten/kota dapat dinyatakan sebagai berikut (Putro \& Pamudji, 2007):

DAU = Celah Fiskal + Alokasi n-

Dimana, celah fiskal $=$ kebutuhan fiskal - kapasitas

\subsubsection{Variabel Dependen}

\subsubsection{Belanja Modal}

Belanja Modal adalah belanja langsung yang digunakan untuk membiayai kegiatan investasi (aset tetap) (Putro, 2009).

Belanja Modal = Belanja Tanah + Belanja Peralatan dan Mesin +
Belanja Gedung dan Bangunan + Belanja Jalan, Irigasi dan Jaringan +
belanja Aset Lainnya

\subsection{Metode Analisis Data}

Seluruh data dalam penelitian diuji dengan menggunakan program statistik SPSS. Alat analisis yang digunakan dalam penelitian ini adalah analisis regresi linier berganda dengan persamaan:

$Y=\alpha+\beta_{1} X_{1}+\beta_{2} X_{2}+\beta_{3} X_{3}+e$

Keterangan:

$\begin{array}{ll}\mathrm{Y} & : \text { Belanja Modal } \\ \alpha & : \text { Konstanta } \\ \beta_{1} \beta_{2} \beta_{3} & : \text { Koefisien regresi } \\ \mathrm{X}_{1} & : \text { Pertumbuhan Ekonomi } \\ \mathrm{X}_{2} & : \text { Pendapatan Asli Daerah (PAD) }\end{array}$

\section{$\mathrm{X}_{3} \quad$ : Dana Alokasi Umum (DAU)}

e $\quad$ :error

Uji statistik deskriptif, dan uji asumsi klasik dilakukan pada penelitian ini, adapun uji asumsi klasik yang akan diuji yaitu: uji normalitas, multikolinearitas, heteroskedasitas dan autokorelasi (Ghozali, . Selanjutnya, dilakukan uji hipotesis menggunakan persamaan dalam regresi linier berganda.

Untuk menguji model persamaan, dilakukan uji signifikansi menggunakan uji $\mathrm{F}$, lalu signifikasi parameter individual menggunakan uji t, dan menguji keterikatan antar variabel dependen dan variabel independen yang bisa dilihat dari besarnya nilai koefisien determinasi $\left(\mathrm{R}^{2}\right)$.

\section{HASIL DAN PEMBAHASAN}

\subsection{Hasil Penelitian}

Hasil pengolahan dan pengujian data menggunakan persamaan model penelitian untuk menguji hipotesis dapat dipaparkan pada tabel 3.1 dibawah ini:

Tabel 1. Hasil pengujian persamaan

\begin{tabular}{|l|l|l|l|l|}
\hline Variabel & Sign & Koef. $\boldsymbol{\beta}$ & t & Sig. \\
\hline PAD & $(-)$ & $-0,919$ & $-2,611$ & 0,040 \\
\hline DAU & $(+)$ & 1,721 & 4,829 & 0,003 \\
\hline R Square & \multicolumn{3}{|c|}{0,889} \\
\hline Adj $R$ Square & \multicolumn{3}{|c|}{0,853} \\
\hline$F$ & \multicolumn{3}{|c|}{0,122} \\
\hline Sig. & \multicolumn{3}{|c|}{001} \\
\hline
\end{tabular}

Hasil regresi berganda model persamaan $\mathbf{Y}=\boldsymbol{\alpha}+\boldsymbol{\beta}_{\mathbf{1}} \mathbf{X}_{\mathbf{1}}+\boldsymbol{\beta}_{\mathbf{2}} \mathbf{X}_{\mathbf{2}}+\boldsymbol{\beta}_{\mathbf{3}} \mathbf{X}_{\mathbf{3}}+\mathbf{e}$ untuk pengujian hipotesis 1 dan 2 pada tabel diatas menjelaskan nilai Adj. $R$ Square sebesar 0,853 yang artinya $85 \%$ variasi besarnya Belanja Modal bisa dijelaskan oleh variasi PAD dan DAU, sedangkan sisanya $15 \%$ dapat dijelaskan oleh variabel lain diluar model persamaan. Untuk mengetahui apakah model yang digunakan telah sesuai (goodness of fit model) atau tidak, adalah dengan cara melihat nilai F. Berdasarkan hasil Uji F diatas, terlihat bahwa nilai $F_{\text {hitung }}>F_{\text {tabel }}$ dimana 24,122.>4,83 (df = $99-3=9 ; \mathrm{k}=3-1=2$ ) dan nilai signifikansi pengujian diatas sebesar 0,001,0,05 $(\alpha=5 \%)$. Hal ini membuktikan bahwa variable PAD dan DAU secara simultan berpengaruh terhadap Belanja Modal dan menunjukan bahwa model persamaan ini fit dan dapat digunakan.

\subsection{Pembahasan}

\subsubsection{Pendapatan Asli Daerah dan Belanja Modal}

Pada tabel 1 di atas, nilai t-statictic Pendapatan Asli Daerah terhadap Belanja Modal sebesar -2,611 < dari tabel 1,29 ( df =99-3=96; $\alpha=5 \%$ ) dan nilai signifikansi $0,4<0,5 \%(\alpha=5 \%)$ dan koefisien $\beta$ sebesar -0,919. Hal ini mengartikan bahwa PAD memiliki pengaruh negatif pada Belanja Modal. Hasil 
yang didapatkan tidak sejalan dengan hipotesis yang dibangun yaitu besar kecilnya belanja modal akan ditentukan dari besar kecilnya PAD, tujuan ini untuk meningkatkan pelayanan publik dan kesejahteraan masyarakat dengan jalan meningkatkan belanja modal, maka Pemda harus berusaha keras untuk menggali PAD yang sebesar-besarnya. Hasil penelitian berbeda dengan penelitian Darwanto dan Yustikasari (2007).

\subsubsection{Dana Alokasi Umum dan Belanja Modal}

Pada tabel 1, nilai t-statistic DAU terhadap Belanja Modal sebesar 4,892 > dari t-tabel 1,29 $(\mathrm{df}=99-3=96$; $\alpha=5 \%)$ dan nilai signifikansi $0,003<0,5 \%(\alpha=5 \%)$. Hasil ini menjelaskan bahwa DAU memiliki pengaruh positif terhadap Belanja Modal. Hasil penelitian sejalan dengan hipotesis yang dibangun, yaitu semakin meningkatnya DAU maka semakin meningkat Belanja Modal. Hal ini disebabkan karena dengan adanya transfer DAU dari pemerintah pusat maka pemerintah daerah bisa mengalokasikan pendapatannya untuk membiayai belanja modal. Penelitian Darwanto dan Yustikasari (2007) dan Putro (2009) mendukung hasil dari penelitian ini .

\section{SIMPULAN DAN SARAN}

\subsection{Simpulan}

Berdasarkan hasil analisis tetang PAD dan DAU terhadap alokasi Belanja Modal di kabupaten/kota Provinsi Jambi maka dapat disimpulkan sebagai berikut:

1. PAD tidak berpengaruh terhadap Belanja Modal. Untuk meningkatkan Belanja Modal, maka pemerintah kota/kabupaten Provinsi Jambi diharapkan dapat meningkatkan PAD. Tingginya penyerapan PAD berhubungan dengan kecenderungan pencapaian tingkat Belanja Modal yang lebih tinggi.

2. DAU berpengaruh terhadap Belanja Modal. Untuk meningkatkan Belanja Modal, maka pemerintah kota/kabupaten Provinsi Jambi diharapkan dapat lebih bijak mengalokasikan DAU agar pelayanan publik dapat ditingkatkan.

3. PAD dan DAU secara simultan berpengaruh signifikan terhadap alokasi Belanja Modal. Penyerapan PAD yang baik dan pengalokasian DAU yang bijak akan meningkatkan Belanja Modal yang berkomitmen dalam mencapai tujuan - tujuan yang telah ditetapkan.

\subsection{Saran}

Penelitian ini memiliki beberapa keterbatasan, berdasarkan hasil dan kesimpulan yang didapatkan, peneliti memberikan saran sebagai berikut:

1. Pemerintah Daerah diharapkan agar lebih mengembangkan potensi dan sektor-sektor ekonomi daerah untuk dapat meningkatkan Pendapatan Asli Daerah (PAD) agar lebih mandiri secara finansial dalam mendanai seluruh aktivitas pemerintahan dalam rangka pelaksanaan otonomi daerah.

2. Pemerintah Daerah juga diharapkan dapat memanfaatkan Pendapatan Asli Daerah (PAD) dan Dana Alokasi Umum (DAU) dengan sebijak mungkin untuk meningkatkan pengadaan infrastruktur, sarana dan prasarana publik yang akan meningkatkan produktivitas publik.

3. Penelitian selanjutnya dapat menambah jumlah sampel dalam penelitian ini dan memperluas area penelitian agar hasil yang diperoleh akan lebih baik ketika digeneralisasikan.

4. Peneliti selanjutnya dapat menambahkan atau menggunakan variabel lain seperti pertumbuhan ekonomi, kebijakan pemerintah, atau fiscal stress.

\section{DAFTAR REFERENSI}

Darwanto, \& Yustikasari, Y. (2007). Pengaruh Pertumbuhan Ekonomi, Pendapatan Asli Daerah, dan Dana Alokasi Umum terhadap Pengalokasian Anggaran Belanja Modal. Simposium Nasional Akuntansi X, 1-25.

Departemen Keuangan Republik Indonesia Direktorat Jendral Perimbangan Keuangan. Dana Alokasi Umum (DAU)

Frelistiyani, W. (2010). Pengaruh Dana Alokasi Umum Terhadap Pendapatan Asli Daerah Dengan Belanja Modal Sebagai. Skripsi, Universitas Diponegoro.

Ghozali, Imam dan Arifin Sabeni. (1997). Pokok-pokok Akuntansi Pemerintahan. Edisi 4. Penerbit BPFE; Yogyakarta.

Ghozali, Imam. (2006). Aplikasi Analisis Multivariate dengan Program SPSS. Badan Penerbit UNDIP; Semarang.

Undang-Undang Republik Indonesia Nomor 32 Tahun 2004.

Mardiasmo. (2002). Akuntansi Sektor Publik. Penerbit Andi. Yogyakarta

Peraturan Pemerintah Republik Indonesia Nomor 65 Tahun 2001 Tentang Pajak Daerah.

Peraturan Pemerintah Republik Indonesia Nomor 55 Tahun 2005 Tentang Dana Perimbangan.

Peraturan Pemerintah Nomor 56 Tahun 2006 tentang Sistem informasi Keuangan Daerah.

Putro, N. , \& Pamudji, S. (2007). Pengaruh Pertumbuhan Ekonomi, Pendapatan Asli Daerah dan Dana Alokasi Umum Terhadap Pengalokasian Anggaran Belanja Modal (Studi Kasus pada Kabupaten/Kota di Provinsi Jawa Tengah). Fakultas Ekonomi Universitas Diponegoro, 3(2), 30-37.

Sekaran, Uma (2017). Research Method for Business : A skill building Approach, 7th edition. New 
York: John wiley and Sons

Sugiyono. (2009). Metode Penelitian Bisnis

(Pendekatan Kuantitatif, Kualitatif, dan R\&D).

Bandung: Alfabeta

Swastika, L. (2013). Pengaruh Pertumbuhan Ekonomi, Pendapatan Asli Daerah dan Dana Alokasi Umum Terhadap Pengalokasian Belanja Modal di Kabupaten Boyolali. Universitas Muhammadiyah Surakarta

Syaiful. (2006). Pengertian dan Perlakuan Akuntansi Belanja Barang dan Belanja Modal Dalam Kaidah Akuntansi Pemerintahan.

Undang-Undang Republik Indonesia Nomor 32 Tahun 2004 Tentang Pemerintahan Daerah

Wertianti, I. G. A. G., \& Dwirandra, A. A. N. . (2013). Pengaruh Pertumbuhan Ekonomi pada Belanja Modal dengan PAD dan DAU Sebagai Variabel Moderasi. E-Jurnal Akuntansi Universitas Udayana, 3, 567-584.

www.djpk.depkeu.go.id 
